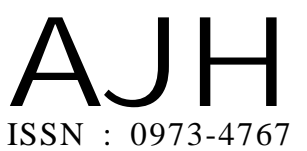

Received : 31.05.2018

Revised : 01.11.2018

Accepted : 15.11 .2018
THEASIAN JOURNALOF HORTICULTURE

Volume 13 | Issue 2 | December, 2018 | 39-44

Visit us $-w w w$.researchjournal.co.in
RESEARCH PAPER

DOI : 10.15740/HAS/TAJH/13.2/39-44

\section{Studies on genetic variability and genetic advance for yield parameters in watermelon (Citrullus lanatus Thumb.)}

\section{A. Anburani}

ABSTRACT : The present investigation was carried out using thirty genotypes of watermelon from diversified origin to elicit information on the quantum of genetic variability, heritability and genetic advance in watermelon in the Department of Horticulture, Faculty of Agriculture, Annamalai University, Annamalai Nagar. Variability studies showed significant differences among the thirty genotypes for all the thirteen characters. Yield per plant was maximum in CL 4 genotype collected from Atchirupakkam in Villupuram district. The characters viz., number of vines per plant, sex ratio, days to first female flowers, node number of first female flower, days to fruit maturity and number of fruits per plant were recorded the maximum in the same genotype. Genetic analysis indicated maximum phenotypic and genotypic co-efficient of variation for single fruit weight and 100 seed weight. The characters viz., fruits diameter, flesh thickness, number of fruits per plant and yield per plant, recorded highest estimate of PCV and moderate estimation of GCV. High heritability coupled with high genetic advance as per cent of mean were observed for single fruit weight, 100 seed weight, number of seeds per fruit, flesh thickness, yield per plant, fruit diameter, vine length, fruit length, number of male flowers, number of fruits per plant, sex ratio and number of primary branches per plant. Moderate estimate of heritability was recorded for number of female flower. Based on mean performance, CL 4 followed by CL 22 and CL 10 were selected as the best genotypes in watermelon for the costal ecosystem, by virtue of their higher yield combined with desirable component characters.

KEY WORDS : Genotypes, Watermelon, Genetic variability, Heritability, Genetic advance

HOW TO CITE THIS ARTICLE: Anburani, A. (2018). Studies on genetic variability and genetic advance for yield parameters in watermelon (Citrullus lanatus Thumb.). Asian J. Hort., 13(2) : 39-44, DOI : 10.15740/HAS/TAJH/13.2/39-44. Copyright@2018 : Hind Agri -Horticultural Society 